\title{
The effect of Yucca schidigera extract dietary supplementation on growth performance, feed and protein utilization of European seabass, Dicentrarchus labrax, fingerlings
}

Bassem Khalil Elkhayat ${ }^{1}$, Abdallah Tageldein Mansour ${ }^{1}$, Walied Mohamed Fayed $^{1}$, Eglal Ali Omar ${ }^{1}$ and Abdel Aziz Moussa Nour ${ }^{2}$

${ }^{1}$ Department of Fish and Animal Production, Faculty of Agriculture (Saba Basha), Alexandria University, Egypt.

${ }^{2}$ Department of Fish and Animal Production, Faculty of Agriculture, Alexandria University, Egypt.

Received: Feb. 12, 2019; Accepted: March. 22, 2019 published: 2019 Vol.9 (3):71-87

\section{Abstract}

A total of 180 apparent healthy European seabass, Dicentrarchus labrax, fingerlings $\left(5.0 \pm 0.5 \mathrm{~g} \mathrm{fish}^{-1}\right)$ were used to investigate the effect of different levels of Yucca, Yucca schidigera, extract (YE) on growth performance, feed utilization and survival rate. Yucca extract were used at level of $0,0.25,0.50$ and $1 \mathrm{~g} \mathrm{YE} \mathrm{kg}^{-1}$ diet for 45 days. The fish were reared in twelve glass aquaria (three replicates per treatment), measuring (70x40x30 cm; approximately 70 liters each) at an initial stocking density of 15 fish aquarium ${ }^{-1}$. The aquaria were supported with artificial aeration and the water exchange rate was $15 \%$ with saline ground water $(32 \%)$. The results indicated that YE dietary supplementation significantly improved final weight, weight gain and specific growth rate in groups fed on 0.50 and $1 \mathrm{~g} \mathrm{YE} \mathrm{kg}^{-1}$ diet compared to the control. Feed intake tended to increase with all groups fed on YE supplemented diet. The feed conversion ratio and protein efficiency ratio improved significantly with the highest two level of YE compared to the control. From the above mentioned, it can be concluded that YE can be used at level of $1 \mathrm{~g} \mathrm{YE} \mathrm{kg}^{-1}$ diet as feed additive in sea bass fingerlings diet for improving growth performance and FCR and protein metabolism and maintaining survival rate. 


\section{Introduction}

European sea bass, Dicentrarchus labrax, is a very important commercial marine fish species in Atlantic coastal lines from Norway to Morocco, the Mediterranean Sea and in the Black Sea (Altan \& Korkut, 2010). Also, it is one of the most economically important fish species farmed in temperate areas (Eroldogan et al., 2004). In Egypt, the production of European sea bass is second to gilthead sea bream, with an estimated production of 30720 tonnes in 2015 and its production has an expectation to be duplicate in the nearest time (GAFRD, 2016).

The intensification of fish farming is an utmost way in the aquaculture industry to cover the human need of protein and attenuate the pressure on the nature fisheries resource (Aubin et al., 2019). With more fish intensification the consumed feed and subsequent excreted nitrogen is increased, which could affect fish metabolism and ambient water bodies (Besson et al., 2016 and Aubin et al., 2019). Therefore, the improvement of protein metabolism and reduction of nitrogen excretion is an inevitable consequence for sustainable aquaculture sector development (Kelly \& Kohler, 2003).

Feed additives including nature (beneficial microorganisms, prebiotics and phytobiotics) and synthetic substances (antibiotics, growth-promoting and hormones) have been used in fish diet to improve fish growth, feed utilization, physiological and immunological, and disease resistance (Lundebye et al., 2010 and Chakraborty \& Hancz, 2011 and Mansour et al., 2017 and Mansour et al., 2018). Meanwhile, due to the public health concerns, the using of synthetic chemicals in animal feed has been minimized or banned because of the residues accumulation risk in the edible tissues (Lundebye et al., 2010) and/or multi-resistant pathogenic bacterial strains (Albuquerque et al., 2007).

The Yucca schidigera is a plant native to the arid region of southwestern USA and Mexico deserts (Headon \& Dawson, 1990). The extract of Yucca schidigera (YE) is a rich source of saponins compounds including, steroidal and glyco-components saponin fractions (Cheeke, 2000 and Ayasan et al., 2005). The YE active components have been used in aquaculture, poultry and livestock industries, mainly to minimize ammonia excretion as an end product of protein metabolism and reduce animal ambient environmental pollution (Headon \& Dawson, 1990 and Hristov et al., 1999 and Sarkar, 1999 and El-Saidy \& Gaber, 2004). The direct application of YE to aquatic animal rearing systems proved appositive effect on reducing ammonia levels in a dose dependent manner in both 
fresh and salt water. Whereas, YE exhibit a potentially safe substance suitable for ammonia reduction and water quality management (SantacruzReyes \& Chien, 2010 and Khalil et al., 2015 and Fayed et al., 2019).

Furthermore, dietary supplementation of YE significantly increased growth performance of Nile tilapia at level of $0.75 \mathrm{mg} \mathrm{kg}^{-1}$ diet and improved the growth of fish fed plant protein based diets to equalized fish fed fish meal based diets (Gaber, 2006). YE was used as a fish feed additive to enhance the protein metabolism and reduce ammonia excretion (Kelly \& Kohler, 2003 and El-Saidy \& Gaber, 2004 and Gaber, 2006). In addition, $Y$. schidigera and $Y$. saponaria induce progressive effects on growth performance and haematological parameters, and decrease total ammonianitrogen excretion in striped catfish, Pangasianodon hypophthalmus (Güroy et al., 2014).

To the authors' knowledge, there is no literature investigating the use of YE as feed additives in the feeding of Eurobean sea bass. Therefore, the aim of this study was to evaluate the effects of YE on growth performance, feed utilization, hematological and immunological status, and stress resistance of European sea bass, Dicentrarchus labrax.

\section{MATERIALS AND METHODS}

\section{Fish and experimental facilities}

A total of 180 apparent healthy European seabass, Dicentrarchus labrax, fingerlings with an average body weight of $5.0 \pm 0.5 \mathrm{~g}^{\text {fish }}{ }^{-1}$ were used. The feeding experiment periods were performed at indoor wet lab. at El- Shreif Fish Farm and Hatchery (Mariuot valley, Alexandria, Egypt) during April to May, 2017. Prior to the start of the experiment, the fish were acclimated to the experimental conditions for two weeks in four indoors circular fiberglass tanks $\left(1 \mathrm{~m}^{3}\right)$ and fed the control basil diet (Table $1)$.

Fish were randomly divided into twelve glass aquaria measuring (70x40x30 cm; approximately 70 liters each) at an initial stocking density of 15 fish aquarium ${ }^{-1}$, representing four experimental treatments (three replicates per treatment). Each aquarium was supported with artificial aeration through air blower and $5 \mathrm{~cm}$ sand stone. The water source was a ground water of saline water well with salinity of $32 \%$, a constant temperature $\left(18 \pm 1^{\circ} \mathrm{C}\right)$ and $\mathrm{pH}(7.0 \pm 0.50)$. Throughout the experimental period, the lightening regime was 12: 12 hour light: dark cycle and the dissolved oxygen was $6.01 \pm 0.2$. Fish excreta were removed by manual siphoning and water exchange rate was $15 \%$ per day and $60 \%$ biweekly during the fish weight sampling. 


\section{Experimental design and diets}

The four experimental treatments were fed one of the following four isonitrogenous ( $45 \%$ crude protein) and isocaloric $\left(\sim 4840 \mathrm{kj} \mathrm{g}^{-1} \mathrm{DM}\right)$ experimental diets for 45 days. The first diet was the control without any Yucca schidigera extract (YE) supplementation $\left(\mathrm{YE}_{0}\right)$, the second diet was supplemented with $0.25 \mathrm{~g} \mathrm{Y}$. schidigera extract $\mathrm{kg}^{-1}$ diet $\left(\mathrm{YE}_{0.25}\right)$, the third diet was supplemented with $0.5 \mathrm{~g} Y$. schidigera extract $\mathrm{kg}^{-1}$ diet $\left(\mathrm{YE}_{0.5}\right)$ and the fourth diet was supplemented with $1 \mathrm{~g} \mathrm{Y}$. schidigera extract $\mathrm{kg}^{-1}$ diet $\left(\mathrm{YE}_{1}\right)$ (Table 1). The selected doses of $Y$. schidigera extract were selected according to the previous work of Kelly and Kohler (2003) and Gaber (2006).

The fish were fed the test diets until apparent satiation two times daily (9:00 a.m. and 2:00 p.m.), six days a week. The apparent satiation was considered after half hour of introducing the diet, then the remaining pellets were collected, dried and weight for accurate determination of feed intake.

The diets were prepared by finely ground the solid ingredients to powder and manually mixed in a plastic container for about 15 minutes to assure its homogeneity. Oil and additives were slowly added to the mixture. Warm distilled water was added gradually until the diet began to clump forming a dough-shaped paste then passed through a commercial meat grinder to form a spaghetti-like extruded diet $(0.3 \mathrm{ml}$ in diameter). The resultant pellets were dried using drying air force oven at $40-45^{\circ} \mathrm{C}$ to a moisture level $<10 \%$ and stored at $-20^{\circ} \mathrm{C}$ until used. The proximate chemical composition (\%) of the formulated diets was analyzed according to (AOAC, 2000) and presented in Table 1. 
Table (1): Ingredients and chemical composition $\left(\mathrm{g} \mathrm{kg}^{-1}\right)$ of the experimental diets

\begin{tabular}{|l|l|l|l|l|}
\hline Ingredients & Yucca $_{0}$ & Yucca $_{0.25}$ & Yucca $_{0.5}$ & Yucca $_{1}$ \\
\hline Fish meal, 68 \% & 300.00 & 300.00 & 300.00 & 300.00 \\
\hline Soy bean meal, 47\% & 375.00 & 375.00 & 375.00 & 375.00 \\
\hline Corn gluten, 60\% & 90.00 & 90.00 & 90.00 & 90.00 \\
\hline Rice bran, 12\% & 65.00 & 65.00 & 65.00 & 65.00 \\
\hline Wheat medling, 13\% & 70.00 & 69.75 & 69.50 & 69.00 \\
\hline Soy bean oil & 40.00 & 40.00 & 40.00 & 40.00 \\
\hline Fish oil & 48.80 & 48.80 & 48.80 & 48.80 \\
\hline Dicalcium Phosphate & 8.00 & 8.00 & 8.00 & 8.00 \\
\hline Vitamins and Minerals mixture* & 2.00 & 2.00 & 2.00 & 2.00 \\
\hline Vitamin C & 0.20 & 0.20 & 0.20 & 0.20 \\
\hline Yucaa, Yucaa shadegrea, extract & & & & \\
\hline Chemical composition $\left(\mathbf{g ~ k g}^{-1} \mathbf{D M}\right)$ & - & 0.25 & 0.50 & 1.00 \\
\hline Dry matter (DM) & 938.00 & 937.50 & 931.80 & 937.70 \\
\hline Crude protein (CP) & 448.60 & 448.80 & 449.70 & 446.00 \\
\hline Ether extract (EE) & 125.60 & 131.00 & 129.80 & 128.90 \\
\hline Nitrogen free extract (NFE) ${ }^{\dagger}$ & 283.40 & 257.00 & 266.50 & 278.60 \\
\hline Crude fiber (CF) & 32.40 & 43.20 & 34.00 & 32.00 \\
\hline Ash & 110.00 & 120.00 & 120.00 & 114.50 \\
\hline Gross energy (GE; kj 100 ${ }^{-1} \mathrm{DM}^{\ddagger}$ & 2041.01 & 2017.35 & 2031.08 & 2039.62 \\
\hline
\end{tabular}

*Composition of vitamin and mineral mixture of $1 \mathrm{~kg}$ : vitamin A - $5000000 \mathrm{IU}$; vitamin D3 - 1000000 IU; vitamin B2 -2.0 g; vitamin E - 750 units; vitamin $\mathrm{K}-1.0 \mathrm{~g}$; calcium pantothenate $2.5 \mathrm{~g}$; nicotinamide $-10.0 \mathrm{~g}$; vitamin B12 - $6.0 \mathrm{~g}$; choline chloride -150.0 $\mathrm{g}$; calcium $-750.0 \mathrm{~g}$; manganese $-27.5 \mathrm{~g}$; iodine $-1.0 \mathrm{~g}$; ion $-7.5 \mathrm{~g}$; zinc $-15.0 \mathrm{~g}$; copper $-2.0 \mathrm{~g}$; cobalt- $0.45 \mathrm{~g}$, calcium carbonate up to (1000 g). $\dagger$ NFE: nitrogen-free extract calculated using the following equation: $\mathrm{NFE}=100$-(crude protein + ether extract + crude fibre + ash).

${ }^{¥}$ Yucaa, Yucaa shadegrea, extract: Vime Yucca (P) ${ }^{\circledR}$ contain $33 \%$ yucca extract with $12 \%$ saponin, produced by Vemedim Corporation, Vietnam.

${ }^{\dagger}$ NFE: nitrogen-free extract calculated using the following equation: NFE $=100$-(crude protein + ether extract + crude fiber + ash).

${ }^{*}$ GE: gross energy calculated on the basis of $23.6,39.4$ and $17.2 \mathrm{k}$ joule gross energy $\mathrm{g}^{-1}$ protein, ether extract and NFE respectively (National research council, 2011). 


\section{Measured parameters}

\section{Growth performance and survival}

The mean final body weight (FBW) in experimental treatment was determined by dividing the total fish weight in each aquarium by the number of fish. Weight gain (WG), specific growth rate (SGR) and survival (\%) were calculated using the following equations according to (Castell \& Tiewes, 1980):

$\mathrm{WG}\left(\mathrm{g} \mathrm{fish}^{-1}\right)=\mathrm{W}_{2}-\mathrm{W}_{1}$

where $\mathrm{W}_{1}$ : initial weight of the fish $(\mathrm{g})$, and $\mathrm{W}_{2}$ : FBW of the fish $(\mathrm{g})$.

ADG $\left(\mathrm{g}_{\text {fish }}{ }^{-1}\right.$ day $\left.^{-1}\right)=\left(\mathrm{W}_{2}-\mathrm{W}_{1}\right) / \mathrm{n}$

where $\mathrm{W}_{1}$ : initial weight of the fish $(\mathrm{g}), \mathrm{W}_{2}$ : FBW of the fish $(\mathrm{g})$, and $\mathrm{n}=$ days.

$\operatorname{SGR}\left(\%\right.$ day $\left.^{-1}\right)=100 \times\left(\ln \mathrm{W}_{2}-\ln \mathrm{W}_{1}\right) /$ days

where $\ln$ is the natural $\log$.

Survival $(\%)=100 \times($ final number of fish/initial number of fish $)$.

\section{Feed and protein utilization}

The feed intake was calculated by dividing the total feed intake $(\mathrm{g})$ for each group on the number of fish in the same group. The feed conversion ratio (FCR) and protein efficiency ratio (PER)were calculated as follow:

$\mathrm{FCR}=$ feed intake $(\mathrm{g}) /$ weight gain $(\mathrm{g})$.

PER = weight gain $(\mathrm{g}) /$ protein intake $(\mathrm{g})$.

\section{Statistical analysis}

All data were subjected to a one-way analysis of variance (ANOVA), when a significant difference was found among treatments. Duncan's multiple range test was performed to rank the groups (Duncan, 1955), using SPSS (Version 17) statistical software.

\section{Results}

\section{Growth performance}

The results of growth performance of different dietary levels of Yucca schidigera extract on the growth performance of culture European sea bass (Dicentrarchus labrax) presented in Table (2). The growth performance of European sea bass, D. labrax, fed supplemented diets with different levels of YE $\left(0,0.25,0.5\right.$ and $1 \mathrm{~g} \mathrm{~kg}^{-1}$ diet $)$ showed a significant increase of FBW with 0.5 and $1 \mathrm{~g} \mathrm{YE} \mathrm{kg}^{-1}$ compared to the control. Moreover, WG, ADG and SGR improved significantly with all YE supplemented diets. The survival (\%) was up to $100 \%$ for all treatments (Figure 1). 
$\mathbf{A}$

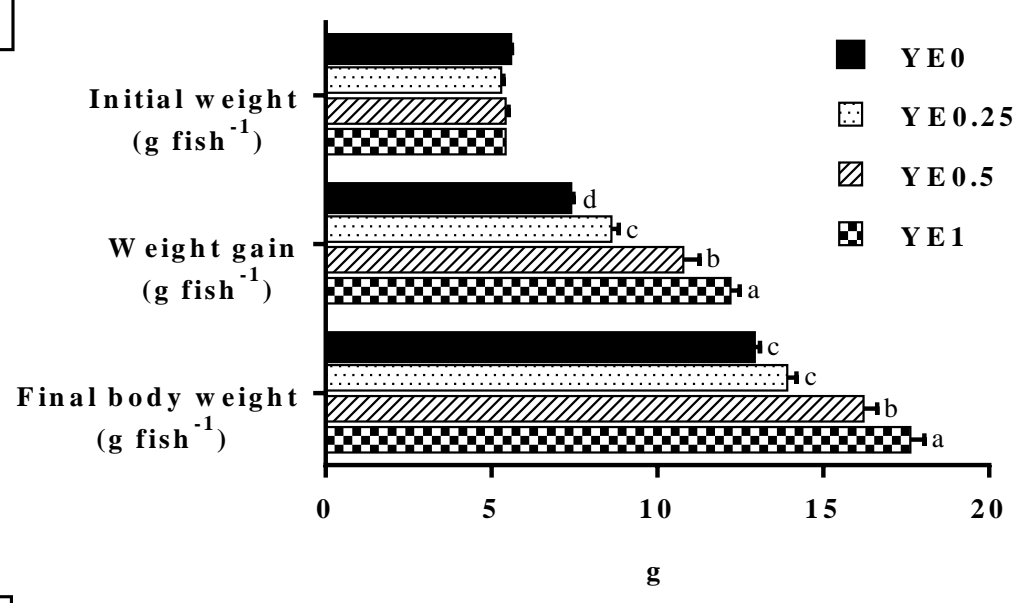

B

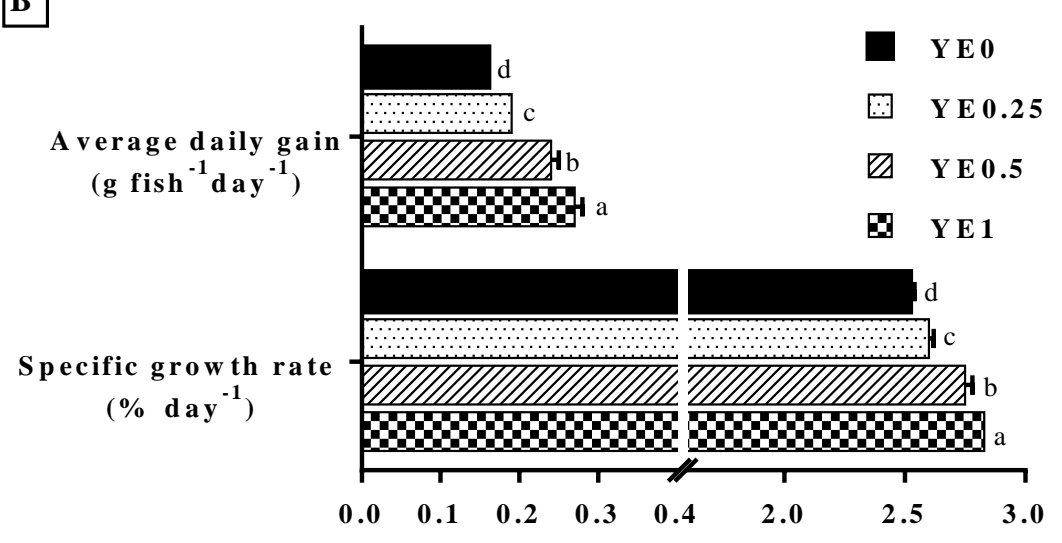

Figure 1. Growth performance (A and B) of European sea bass, Dicentrarchus labrax, fed supplemented diets with different levels of Yucca schidigera extract $\left(\mathrm{g} \mathrm{kg}^{-1}\right)$ for 45 days $(\mathrm{n}=3$; means $\pm \mathrm{SE}$ ). Columns bearing with different superscript differ significantly $(P \leq$ $0.05)$. 


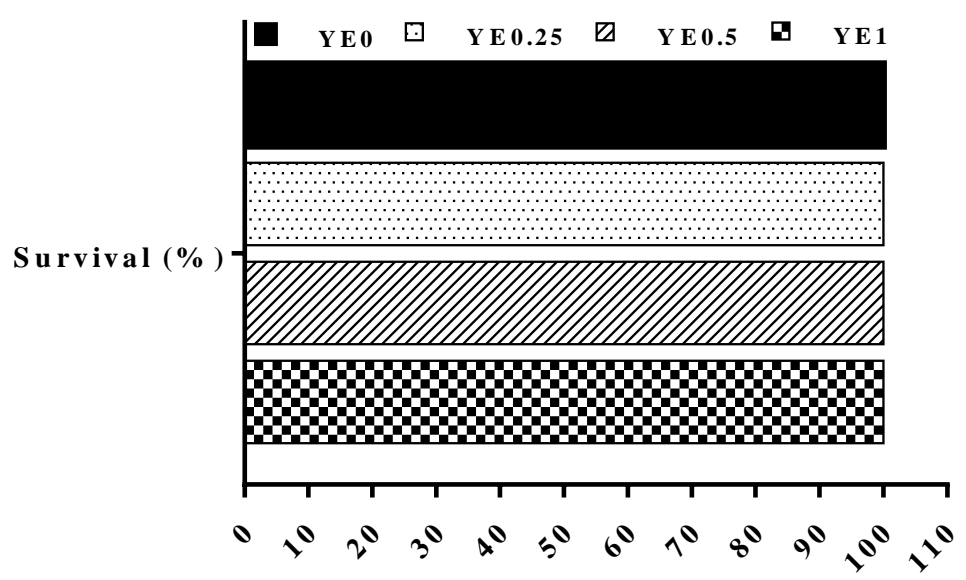

Figure 2. Survival (\%) of European sea bass, Dicentrarchus labrax, fed supplemented diets with different levels of Yucca schidigera extract $\left(\mathrm{g} \mathrm{kg}^{-1}\right)$ for 45 days $(\mathrm{n}=3$; means \pm $\mathrm{SE})$.

\section{Feed and protein utilization}

The effect of YE supplementation on feed intake and protein utilization presented in Figure 3. The results showed that feed intake did not differ significantly among different treatments. Meanwhile, FCR improved significantly with all YE supplemented treatments compared to the control group. The PER increased significantly with the higher two doses of YE $\left(0.5\right.$ and $\left.1 \mathrm{~g} \mathrm{YE} \mathrm{kg}^{-1}\right)$ compared to the control group. 


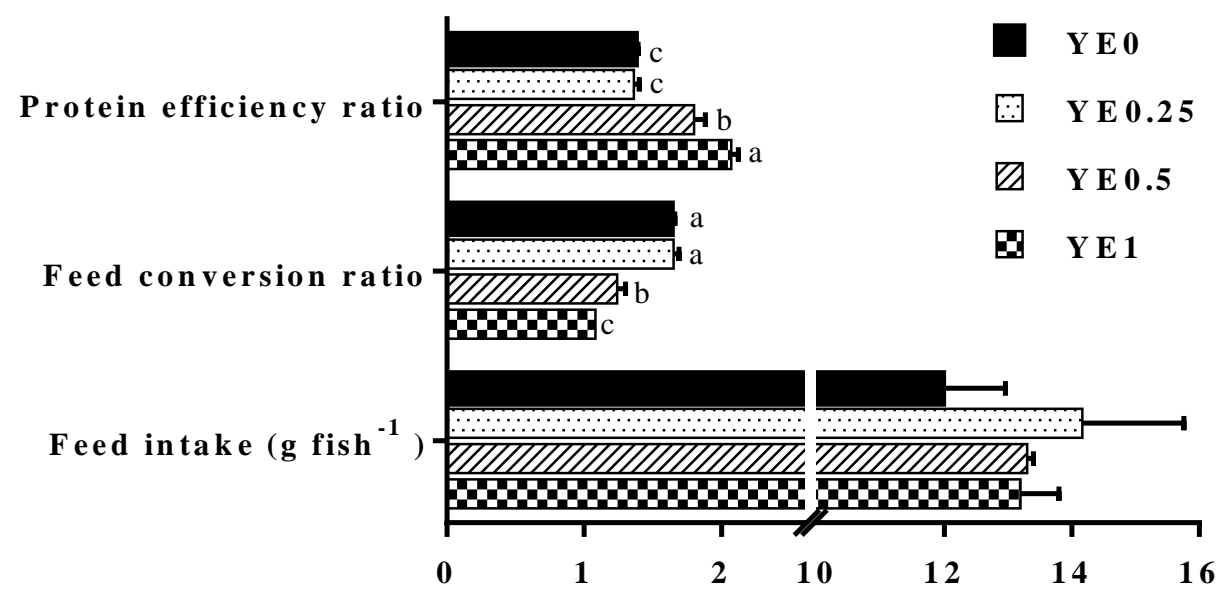

Figure 3. Feed intake feed and protein utilization of European sea bass, Dicentrarchus labrax, fed supplemented diets with different levels of Yucca schidigera extract $\left(\mathrm{g} \mathrm{kg}^{-1}\right)$ for 45 days $(n=3$; means $\pm S E)$. Columns bearing with different superscript differ significantly $(P \leq 0.05)$.

\section{Discussion}

As marine fish feed cost is one of the detrimental factors affecting mariculture expanding, improving the metabolic efficiency and feed utilization of these diets is a progress research trend especially protein metabolism as the highest price of feed components (Goda et al., 2019). Also, improving protein metabolism is necessary to control the nitrogenous waste in aquaculture systems to meet effluent standards (Kelly $\&$ Kohler, 2003). Furthermore, the good aquatic animal health is a result of high quality feed and suitable water condition, at the same time, maintaining the animal healthy is a prominent factor for better growth and feed utilization (Trichet, 2010 and Mansour et al., 2017 and Mansour et al., 2018 and Wang et al., 2018).

The effect of YE dietary supplementation at different level $(0,0.25,0.5$ and $1 \mathrm{~g} \mathrm{~kg}^{-1}$ diet) on growth performance of European sea bass D. labrax were investigated and the results showed an improvement of final weight by $8.16,26.02$ and $36.98 \%$ with $0.25,0.5$ and $1 \mathrm{~g} \mathrm{YE} \mathrm{kg}^{-1}$, respectively compared to the control. In consistence with the present findings, channel catfish, Ictalurus punctatus, fry fed on YE supplemented diets at dose of 1 $\mathrm{g} \mathrm{kg}^{-1}$ diet exhibited the higher significant weight gain (Kelly \& Kohler, 2003). Also, growth performance of Nile tilapia, O. niloticus, improved significantly with feeding YE (El-Saidy \& Gaber, 2004) not only but also 
YE at level of $0.75 \mathrm{mg} \mathrm{kg}^{-1}$ diet improved the growth of fish fed plant protein based diets to equalized fish fed fish meal based diets (Gaber, 2006). In addition, growth of striped catfish, Pangasianodon hypophthalmus, improved significantly with $Y$. schidigera and $Y$. saponaria extract dietry supplementation (Güroy et al., 2014). The effect of YE on growth was confirmed in several animal species including, white shrimp, Litopenaeus vannamei, (Yang et al., 2014) Arbor Acres broilers (Su et al., 2016) growing rabbit (Amber et al., 2004 and Földešiová et al., 2017).

Regarding the feed and protein utilization, the current findings showed an improvement of feed intake in YE supplemented group, which illustrated that YE did not negatively affected the diet palatability. Also, the increase in feed intake in the present study may due to the hormonal regulation of YE as reported by (Kucukkurt \& Dundar, 2013), where YE increased leptin and insulin level in plasma of treated rats.

Furthermore, FCR improved significantly with YE supplementation at the higher two doses $\left(0.5\right.$ and $1 \mathrm{~g} \mathrm{~kg}^{-1}$ diet $)$ by 39 and $55 \%$ compared to non-supplemented group, respectively. Also, the PER increased significantly with 0.5 and $1 \mathrm{~g} \mathrm{YE} \mathrm{kg}^{-1}$ diet by 43 and $70 \%$, respectively. In the same sense, YE improved feed and protein utilization of channel catfish, Ictalurus punctatus, (Kelly \& Kohler, 2003), Nile tilapia, $O$. niloticus, (El-Saidy \& Gaber, 2004) (Gaber, 2006), striped catfish, Pangasianodon hypophthalmus (Güroy et al., 2014), white shrimp, Litopenaeus vannamei, (Yang et al., 2014) and broilers and rabbit (Amber et al., 2004 and Su et al., 2016 and Földešiová et al., 2017). The nitrogen utilization improved by $24.3 \%$ in rabbit fed YE $\left(0.25 \mathrm{~g} \mathrm{~kg}^{-1}\right)$ supplemented diet than the control group (Amber et al., 2004). In contrast, the present findings did not showed any improvement of PER with the same level of YE supplementation $\left(0.25 \mathrm{~g} \mathrm{~kg}^{-1}\right)$ and the PER improved with the higher level of YE supplementation, this may be attributed to the different experimental animals and the completely difference of digestive system.

The improvement of growth performance, FCR and PER in the present study could attributed to the YE active components which include steroidal and glyco-components saponin fractions (Cheeke, 2000 and Ayasan et al., 2005). The presence of steroidal saponin can improve the absorption of nutrients (Yang et al., 2014) by changing enterocytes membrane structure and reducing surface tension (Goetsch \& Owens, 1985) and increasing the permeability of intestinal membranes to dietary nutrients (Francis et al., 2002). In addition, YE can improve the intestinal wall integrity via increasing the thickness of intestinal mucosa and preventing the invasion 
of certain kinds of viruses, improving the animal immunity and suppress the intestinal bacterial growth (Huang et al., 2005).

Furthermore, the improvement of protein utilization with increasing YE in the present study may attributed to the improvement of digestive enzymes activity (Liu et al., 2005). Also, the protein retention could due to the reduction of ammonia excretion and fecal nitrogen concentrations in channel catfish (Kelly \& Kohler, 2003) and reduced blood urea and caecal ammonia concentrations in rabbit (Amber et al., 2004), whereas, YE active components have a great adsorption capacity volatile compounds, including ammonia and hydrogen sulfide (Cheeke, 2000). The effect of YE on hematological and immunological status of European seabass were studied and presented in Fayed et al. (2019).

\section{Conclusion}

It can be concluded that, dietary supplementation of YE significantly improved growth performance in groups fed on 0.50 and $1 \mathrm{~g} \mathrm{YE} \mathrm{kg}^{-1}$ diets compared to the control. The feed conversion ratio and protein efficiency ratio improved significantly with the highest two level of YE compared to the control. From the above mentioned, YE can be used at level of $1 \mathrm{~g}$ YE $\mathrm{kg}^{-1}$ diet as feed additive in sea bass fingerlings diet for improving growth performance and FCR and protein metabolism and maintaining survival rate.

\section{References}

Albuquerque, W., Macrae, A., Sousa, O., Vieira, G., \& Vieira, R. (2007). Multiple drug resistant Staphylococcus aureus strains isolated from a fish market and from fish handlers. Brazilian Journal of Microbiology, 38(1), 131-134.

Altan, O., \& Korkut, A. Y. (2010). Effects of temperature and dietary carbohydrate level to growth performance and feed digestibility of European sea bass Juveniles (Dicentrarchus Labrax). Bulgarian Journal of Agricultural Science, 16(6), 775-782.

Amber, K., Akout, H. M., \& Hamed, R. S. (2004). Effect of feeding diets containing yucca extract or probiotic on growth, digestibility, nitrogen balance and caecal microbial activity of growing new zealand white rabbits. Paper presented at the $8^{\text {th }}$ World Rabbit Congress - September 7-10, Puebla, Mexico.

AOAC. (2000). International Official methods of Analysis, $17^{\text {th }}$ edition. Association of Official Analytical Chemists (AOAC): Arlington, Virginia, USA. 
Aubin, J., Callier, M., Rey-Valette, H., Mathe, S., Wilfart, A., Legendre, M., . . Masson, G. (2019). Implementing ecological intensification in fish farming: definition and principles from contrasting experiences. Reviews in Aquaculture, 11(1), 149-167.

Ayasan, T., Yurtseven, S., Baylan, M., \& Canogullari, S. (2005). The effects of dietary Yucca schidigera on egg yield parameters and egg shell quality of laying Japanese quails (Coturnixcoturnix japonica). International Journal of Poultry Science, 4, 159-162.

Besson, M., Aubin, J., Komen, H., Poelman, M., Quillet, E., Vandeputte, M., . . . De Boer, I. (2016). Environmental impacts of genetic improvement of growth rate and feed conversion ratio in fish farming under rearing density and nitrogen output limitations. Journal of cleaner production, 116, 100-109.

Castell, J. D., \& Tiewes, K. (1980). Report of the EIFAC, IUNS and ICES working group on the standardization of methodology in fish research, Hamburg, FRG, 21-23 March 1979.IFAC tech. Pap.(3) 24. .

Chakraborty, S. B., \& Hancz, C. (2011). Application of phytochemicals as immunostimulant, antipathogenic and antistress agents in finfish culture. Reviews in Aquaculture, 3, 103-119.

Cheeke, P. R. (2000). Actual and potential applications of Yucca schidigera and Quillaja saponaria saponins in human and animal nutrition. Journal of Animal Science, 77, 1-10.

Duncan, D. (1955). Multiple range and multiple F test. Biometric, 11, 142. doi: $10.2307 / 3001478$

El-Saidy, D. M. S., \& Gaber, M. M. A. (2004). Effect of Yucca schidigera on water quality and growth performance of Nile tilapia (O. niloticus L) fingerlings. EgyptianJournal of Aquatic Biology and Fisheries, 8, 3350 .

Eroldogan, O. T., Kumlu, M., \& Aktas, M. (2004). Optimum feeding rates European sea bass (Dicentrarchus labrax L.) reared in seawater and freshwater. Aquaculture Nutrition, 231, 501-515.

Fayed, W. M. A., Khalil, R. H., Sallam, G. R., Mansour, A. T., El-khayata, B. K., \& Omar, E. A. (2019). Estimating the effective level of Yucca schidigera extract for improvement of the survival, haematological parameters, immunological responses and water quality of European seabass juveniles (Dicentrarchus labrax). . Aquaculture report, 15, 100208.

Földešiová, M., Baláži, A., Chrastinová, L., Pivko, J., Kotwica, J., Harrath, 
A. H., Sirotkin, A. V. (2017). Yucca schidigera can promote rabbit growth, fecundity, affect the release of hormones in vivo and in vitro, induce pathological changes in liver, and reduce ovarian resistance to benzene. Animal Reproduction Science, http://dx.doi.org/10.1016/j.anireprosci.2017.1006.1001.

Francis, G., Kerem, Z., Makkar, H. P. S., \& Becker, K. (2002). The biological action of saponins in animal systems: a review. British Journal of Nutrition, 88, 587-605.

Gaber, M. M. (2006). The effects of plant-protein-based diets supplemented with yucca on growth, digestibility, and chemical composition of Nile tilapia (Oreochromis niloticus, L) fingerlings. Journal of the World Aquaculture Society, 37(1), 74-81.

GAFRD. (2016). Fish statistic year book, $26^{\text {th }}$ edition General authorty for fisheries resources development, Minestry of Agriculture and Land Reclamation, Egypt.

Goda, A. A. S., Srour, T. M., Omar, E., Mansour, A. T., Baromh, M. Z., Mohamed, S. A., Davies, S. J. (2019). Appraisal of a high protein distiller's dried grain (DDG) in diets for European sea bass, Dicentrarchus labrax, fingerlings on growth performance, haematological status and related gut histology. Aquaculture Nutrition, DOI: 10.1111/аnu. 12898

Goetsch, A. L., \& Owens, F. N. (1985). Effects of sarsaponin on digestion and passage rates in cattle fed medium to low concentrate. Journal of Dairy Science, 68, 2377-2384.

Güroy, B., Mantoğlu, S., Kayalı, S., \& Şahin, İ. (2014). Effect of dietary Yucca schidigera extract on growth, total ammonia-nitrogen excretion and haematological parameters of juvenile striped catfish $P$ angasianodon hypophthalmus. Aquaculture research, 45(4), 647-654.

Headon, D. R., \& Dawson, K. A. (1990). Yucca extract controls atmospheric ammonia levels. Feed stuffs, 62(29).

Hristov, A. N., McAllister, T. A., van Herk, F. H., Cheng, K.-J., Newbold, C. J., \& Cheeke, P. R. (1999). Effect of Yucca schidigera on ruminal fermentation and nutrient digestion in heifers. Journal of Animal Science, 77, 2554-2563.

Huang, H. Q., Zheng, G. H., \& Chen, F. R. (2005). Yucca schidigera planta natural multi-functional feed additives. Animal Science Abroad, 32(10), 61-64.

Kelly, A. M., \& Kohler, C. C. (2003). Effects of Yucca schidigera extract 
on growth, nitrogen retention, ammonia excretion, and toxicity in channel catfish, Ictalurus punctatus and hybrid tilapia, Oreochromis mossambicus $\times$ O. niloticus. Journal of the World Aquaculture Society, 34(2), 156-161.

Khalil, R. H., Saad, T. T., Ragab, H. M. G., \& Mohammed, R. A. E. A. (2015). Effect of Yucca Schidigera on water quality of Nile Tilapia fingerlings. Journal of Amirican Science, 11(12), 83-88.

Kucukkurt, I., \& Dundar, Y. (2013). Effects of dietary Yucca schidigera supplementation on plasma leptin, insulin, iodated thyroid hormones and some biochemical parameters in rats. Revue Méd. Vét., 164(7), 362-367.

Liu, C. L., Sun, H. X., Li, C. S., \& Liu, Y. B. (2005). The application of sarsaponin on improving the environment of barn and discussion of mechanism. System Sciences and Comprehensive Studies in Agriculture, 3, 14-16.

Lundebye, A. K., Hove, H., Mage, A., Bohne, V. J. B., \& Hamre, K. (2010). Levels of synthetic antioxidants (ethoxyquin, butylated hydroxytoluene and butylated hydroxyanisole) in fish feed and commercially farmed fish. Food Additives and Contaminants Part AChemistry Analysis Control Exposure \& Risk Assessment, 27, 16521657.

Mansour, A. T., Goda, A. A., Omar, E. A., Khalil, H. S., \& Esteban, M. A. (2017). Dietary supplementation of organic selenium improves growth, survival, antioxidant and immune status of meagre, Argyrosomus regius, juveniles. Fish \& Shellfish Immunology, 68, 516-524.

Mansour, A. T., Miao, L., Espinosa, C., García-Beltrán, J. M., Francisco, D. C. C., \& Esteban, M. Á. (2018). Effects of dietary inclusion of Moringa oleifera leaves on growth and some systemic and mucosal immune parameters of seabream. Fish Physiol Biochem, 44, 12231240 .

National research council. (2011). Nutrient requirements of fish and shrimp. Washington, DC, USA: National academies press.

Santacruz-Reyes, R. A., \& Chien, Y.-H. (2010). Ammonia reduction in seawater by Yucca schidigera extract: efficacy analysis and empirical modelling. Aquaculture research, 41, 1221-1228.

Sarkar, S. K. (1999). Role of plant glycocomponents (De-odorase) on freshwater prawn, Macrobrachium malcolmsonii in ponds. Journal of Environmental Biology, 20, 299-301. 
Su, J.-L., Shi, B.-L., Zhang, P.-F., Sun, D.-S., Li, T.-Y., \& Yan, S.-M. (2016). Effects of Yucca Extract on Feed Efficiency, Immune and Antioxidative Functions in Broilers. BRAZILIAN ARCHIVES OF BIOLOGY AND TECHNOLOGY, 59, e16150035.

Trichet, V. V. (2010). Nutrition and immunity: an update. Aquaculture research, 41(3), 356-372.

Wang, A. R., Ran, C., Ringø, E., \& Zhou, Z. G. (2018). Progress in fish gastrointestinal microbiota research. Reviews in Aquaculture, 10(3), 626-640.

Yang, Q.-h., Tan, B.-p., Dong, X.-h., Chi, S.-y., \& Liu, H.-y. (2014). Effects of different levels of Yucca schidigera extract on the growth and nonspecific immunity of Pacific white shrimp (Litopenaeus vannamei) and on culture water quality. Aquaculture, 10.1016/j.aquaculture.2014.1011.1029. 






\section{باسم خليل الخياط'، عبدالله تاج الدين منصور'، وليد محمد فايد'، إجلال علي عمر'،

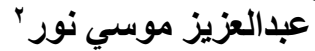 'قسم الإنتاج الحيواني و السمكي، كلية الزر اعة (سابا بانشا)، جامعة الإسكندرية. "قسم الإنتاج الحيو اني و السمكي، كلية الزراعة الإنة ، جامعة الإسكندرية.}

*E-mail: Basemelkhayat@gmail.Com; Mobile: +201002863612

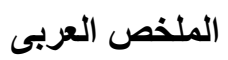

تم إستخدام ، 1 1 إصباعية قاروص اوربي بمتوسط وزن ه جم لكل سمكه، لدر اسة تأثير

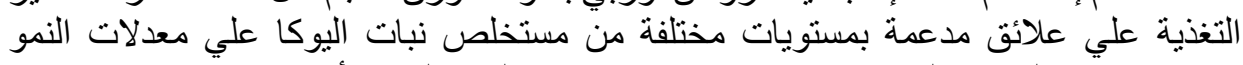

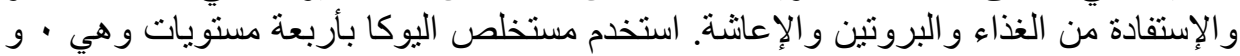



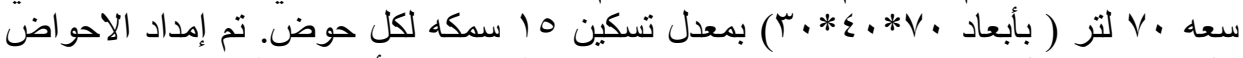



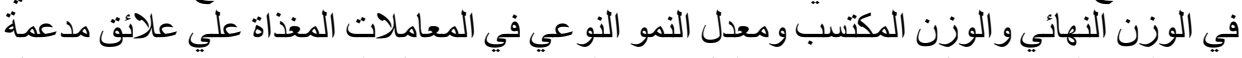

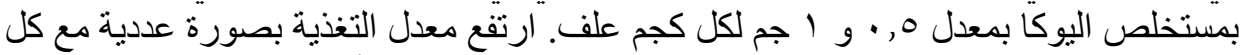

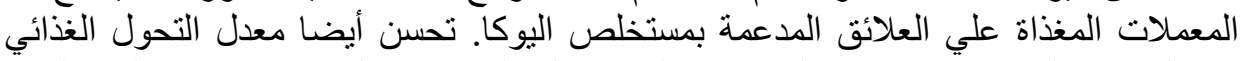

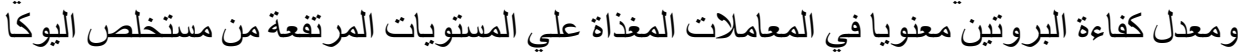


علف لتحسين معدلات النمو والإستفادة من الغذاء وميتابوليزم البروتين في إصباعياتيات أسماك القاروص الأوربي. 
